\title{
First report of a tetracycline-inducible gene expression system for mollicutes
}

\author{
Marc Breton, ${ }^{1,2}$ Evelyne Sagné, ${ }^{3,4}$ Sybille Duret, ${ }^{1,2}$ Laure Béven, ${ }^{1,2}$ \\ Christine Citti ${ }^{3,4}$ and Joël Renaudin ${ }^{1,2}$ \\ ${ }^{1}$ INRA, UMR 1090 Génomique Diversité et Pouvoir Pathogène, F-33883 Villenave d'Ornon, France \\ ${ }^{2}$ Université de Bordeaux 2, UMR 1090 Génomique Diversité Pouvoir Pathogène, F-33883 \\ Villenave d'Ornon, France \\ ${ }^{3}$ INRA, UMR 1225 Interactions hôtes agents pathogènes, F-31076 Toulouse, France \\ ${ }^{4}$ Université de Toulouse, ENVT, UMR 1225 Interactions hôtes agents pathogènes, F-31076 \\ Toulouse, France
}

Correspondence

Joël Renaudin

renaudin@bordeaux.inra.fr

Received 27 August 2009

Revised 22 September 2009

Accepted 25 September 2009

\begin{abstract}
Inducible promoter systems are powerful tools for studying gene function in prokaryotes but have never been shown to function in mollicutes. In this study we evaluated the efficacy of the tetracycline-inducible promoter $\mathrm{P} x y / /$ tet $\mathrm{O}_{2}$ from Bacillus subtilis in controlling gene expression in two mollicutes, the plant pathogen Spiroplasma citri and the animal pathogen Mycoplasma agalactiae. An S. citri plasmid carrying the spiralin gene under the control of the $x y / / t e t \mathrm{O}_{2}$ tetracycline-inducible promoter and the TetR repressor gene under the control of a constitutive spiroplasmal promoter was introduced into the spiralin-less S. citri mutant GII3-9a3. In the absence of tetracycline, expression of TetR almost completely abolished expression of spiralin from the $x y l / \mathrm{tet}_{2}$ promoter. Adding tetracycline $\left(>50 \mathrm{ng} \mathrm{ml}^{-1}\right)$ to the medium induced high-level expression of spiralin. Interestingly, inducible expression of spiralin was also detected in vivo: in $S$. citri-infected leafhoppers fed on tetracycline-containing medium and in S. citri-infected plants watered with tetracycline. A similar construct was introduced into the $M$. agalactiae chromosome through transposition. Tetracycline-induced expression of spiralin proved the TetR-Pxyl/tetO $\mathrm{O}_{2}$ system to be functional in the ruminant pathogen, suggesting that this tetracycline-inducible promoter system might be of general use in mollicutes.
\end{abstract}

\section{INTRODUCTION}

Mollicutes are a class of wall-less bacteria having arisen from ancestors common to low-G $+\mathrm{C}$ Gram-positive bacteria by a so-called regressive evolution (Weisburg et al., 1989). Various species are pathogenic to man, animals and plants, in which they may cause severe diseases. Due to their small genome sizes and limited metabolic pathways, they are commonly described as the simplest self-replicating organisms (Peterson \& Fraser, 2001; Sirand-Pugnet et al., 2007). Genomes of mollicutes have been among the very first to be sequenced. However, due to the lack of suitable tools, genetic studies have long been limited to a few mollicute species. In the plant pathogen Spiroplasma citri, knockout mutants were first generated through insertional (Tn4001) mutagenesis (Foissac et al., 1997; Jacob et al., 1997). Then artificial oriC plasmids were engineered to vectors for both expression of cloned genes and specific gene targeting through homologous recombination (Lartigue et al., 2002; Renaudin et al., 1995; Renaudin \& Lartigue, 2005), leading to the identification of genes involved in insect transmis- sion (Duret et al., 1999; Killiny et al., 2006) and pathogenicity (André et al., 2005; Gaurivaud et al., 2000). These vectors were further improved to enhance the probability of selecting rare recombination events and to produce unmarked mutations through the use of the transposon $\gamma \delta \mathrm{TnpR} / \mathrm{res}$ recombination system (Duret et al., 2005). Subsequently, oriC plasmids have been developed in various mycoplasma species including Mycoplasma pulmonis (Cordova et al., 2002), species of the Mycoplasma mycoides cluster (Janis et al., 2005; Lartigue et al., 2003), Mycoplasma gallisepticum (Lee et al., 2008) and Mycoplasma agalactiae (Chopra-Dewasthaly et al., 2005a). In M. mycoides subsp. mycoides SC, a Tn 4001 derivative combined with the $\gamma \delta \mathrm{TnpR} / \mathrm{res}$ system has been used to produce insertional mutants free of antibiotic-resistance genes (Janis et al., 2008). More recently, characterization of the replication and stability regions of $S$. citri natural plasmids led to the construction of new vectors that overcome disadvantages of oriC plasmids for expressing genes in spiroplasmas (Breton et al., 2008). However, in spite of these recent advances, some of the molecular tools commonly used in more conventional bacteria have not 
been re-engineered for use in mollicutes. Among these, the availability of an inducible promoter system, in particular, is critical for studying gene function. In fact, the control of gene expression has a wide range of applications such as production of conditional knockout mutants (Kamionka et al., 2005), conditional expression of toxin genes (Carroll et al., 2007), plasmid loss through inducible counterselection (Bae \& Schneewind, 2006), titration of gene expression in the host cells (Corrigan et al., 2007), and antisense-mediated silencing of essential genes (Blokpoel et al., 2005).

Mollicutes are known as having lost most of their regulatory systems during their reductive evolution. Very few regulators have been identified and studies on transcription regulation are still limited (Halbedel et al., 2007; Musatovova et al., 2006; Weiner et al., 2003). In S. citri, the existence of inducible promoters has been suggested by the fact that transcription of the fructose and glucose operons is enhanced in the presence of the relevant sugars (André et al., 2005; Gaurivaud et al., 2001). Nevertheless, these operons are still expressed at a basal level in the absence of added sugars, indicating that they are not strongly repressed. Indeed, regulator FruR was shown to act as an activator of the fructose operon (Gaurivaud et al., 2001) and no repressor was identified.

A variety of regulated promoter systems have been considered for use in Gram-positive bacteria. These include the Xyl-xylR-inducible promoter, the pSpac-lacI system, the arabinose-inducible $\mathrm{P}_{\mathrm{BAD}}$ promoter, and the TetRcontrolled $x y l / t e t \mathrm{O}_{2}$ promoter (Kamionka et al., 2005), in which expression of the target gene is induced in the presence of tetracycline. Tetracycline-induced expression systems have been widely used because tetracycline and its derivatives penetrate most cells, leading to sensitive regulation in bacteria within their eukaryotic host.

The aim of the present study was to evaluate such a tetracycline-inducible promoter system in mollicutes. Here we report the successful tetracycline-controlled expression of spiralin in S. citri both in vitro in cell-free medium and in vivo within the leafhopper vector and in the host plant. The tetracycline-inducible expression of spiralin was also demonstrated in the ruminant mycoplasma M. agalactiae.

\section{METHODS}

Bacterial strains, transformation and growth conditions. Escherichia coli DH10B was used as the host strain for cloning experiments and plasmid propagation. S. citri GII3 wild-type strain was originally isolated from its leafhopper vector Circulifer haematoceps captured in Morocco (Vignault et al., 1980). The spiralin-less S. citri mutant GII3-9a3 is identical to the previously described GII39a2 (Duret et al., 2003) except that, in contrast to GII3-9a2 which lacks pSci5, GII3-9a3 contains the whole set of plasmids of the wildtype strain GII3. Due to the presence of the tetM gene in its chromosome, S. citri GII3-9a3 is tetracycline resistant. S. citri was grown at $32{ }^{\circ} \mathrm{C}$ in SP4 medium (Whitcomb, 1983) from which fresh yeast extract was omitted. Electrotransformation of $S$. citri with plasmid DNA was carried out as previously described (Stamburski et al., 1991) with 1-5 $\mu$ g DNA. S. citri transformants were selected by plating on solid SP4 medium supplemented with $100 \mu \mathrm{g}$ gentamicin $\mathrm{ml}^{-1}$. Individual colonies were picked and grown in broth medium containing $100 \mu \mathrm{g}$ gentamicin $\mathrm{ml}^{-1}$. For induction experiments, tetracycline hydrochloride (Sigma) was added to the SP4 medium at concentrations ranging from 5 to $1000 \mathrm{ng} \mathrm{ml}^{-1}$. M. agalactiae type strain PG2 was grown at $37{ }^{\circ} \mathrm{C}$ in SP4 medium. Transformation was carried out by electroporation (Chopra-Dewasthaly et al., 2005b).

\section{DNA isolation, Southern blot hybridization and protein immu-} noblotting. Preparation of spiroplasmal genomic and plasmid DNA, and Southern blot hybridization with appropriate digoxigenin-11dUTP-labelled probes have been described elsewhere (André et al., 2003; Breton et al., 2008). The $\mathrm{Gm}^{\mathrm{r}}$ probe specific to the $3^{\prime}$-terminal region of the aacA-aphD gene of Tn4001 (Rouch et al., 1987) was generated by PCR amplification of pBOG1 using primers MG3 (5'-AAGCTTGCGCATCATTGGATG-3') and GR1 (5'-AAGATATAGTTGAAGAATATTATCC-3') in the presence of digoxigenin-11dUTP. This probe encompasses the $3^{\prime}$ end sequences of IS 256 that are located immediately upstream and downstream of the aacA-aphD gene. For protein immunoblots, S. citri and M. agalactiae from $1 \mathrm{ml}$ late-exponential-phase cultures $\left(10^{8}-10^{9}\right.$ c.f.u. $\left.\mathrm{ml}^{-1}\right)$ were pelleted by centrifugation and dispersed in $50 \mu \mathrm{l}$ HS buffer [8 mM HEPES (pH 7.4), $280 \mathrm{mM}$ sucrose], of which $25 \mu \mathrm{l}$ was spotted under vacuum onto a nitrocellulose membrane. In the case of insects, five insects were harvested 10-15 days after injection, crushed in $1 \mathrm{ml} \mathrm{SP} 4$ and filtered $(0.22 \mu \mathrm{m}$ pore size) before $50-100 \mu \mathrm{l}$ filtrate was spotted onto the membrane. For spiroplasma-infected plants, $100 \mathrm{mg}$ of midribs was ground in $1 \mathrm{ml} \mathrm{SP} 4$ and filtered $(0.22 \mu \mathrm{m}$ pore size). Immunoblotting was carried out as described previously (Duret et al., 2003) except that spiralin reacting with polyclonal, monospecific antibodies used as primary antibodies was visualized by using a goat anti-rabbit immunoglobulin G-peroxidase conjugate and the Super Signal West Pico chemoluminescent substrate (Pierce).

Plasmid constructions. Plasmid pSR2 and the S. citri oriC plasmid pBOG1 have been described elsewhere (Lartigue et al., 2002; Renaudin, 2002). For plasmid constructions, PCR amplification of the various DNA fragments was performed using Phusion DNA polymerase (Finnzymes). To construct pBOGS (Fig. 1), the spiralin gene was amplified from $S$. citri GII3 genomic DNA template using primers Spi-BglII-F (5'-GAGAAAGGAGATCTAAGAAATGAAAAAACT-3'; BglII site italicized) and Spi-BglII-R (5'-CTAAATAAGATCTAGTTAATTCTTATCCTGCA- $3^{\prime}$ ) and the BglII-digested DNA fragment was inserted into the BglII site of pBOG1. To generate pXTS (Fig. 1), a DNA fragment corresponding to the ClaI cassette bearing the $x y l / t e t \mathrm{O}_{2}$ promoter region from pWH105 (Kamionka et al., 2005) fused with the seven first codons of the S. citri spiralin gene was synthesized and inserted into the unique ClaI site of pBOGS. In pXTS, the spiralin gene was inserted in the opposite orientation of the dnaA gene (in the $S$. citri oriC) and hence could only be transcribed from the $x y l / t e t \mathrm{O}_{2}$ promoter. The TetR gene was PCR amplified from pLew90 (kindly provided by Dr V. Coustou, Université Victor Segalen Bordeaux 2, France) with primers TetRBglII-F (5' -CAACGAAGATCTCATATGTCTAGATTAGATAA-3') and TetR-BamHI-R (5'-GGCAGGATCCTTAAGACCCACTTTCACAT- $\left.3^{\prime}\right)$. The BamHI + BglII-digested amplicon was inserted into the BglII-linearized pSR2 to yield pSTR. To construct pXTST, the 967 bp PstI cassette containing the TetR repressor gene downstream of the spiralin gene promoter was retrieved from pSTR and combined with the PstI-linearized pXTS (Fig. 1). Finally, a 2608 bp fragment comprising the TetR and spiralin genes was amplified from pXTST with primer set XTST-EcoRI-F (5'-TAAAGGGAATTCAAGCTTGCATGCCTGCAG-3') and XTST-EcoRI-R (5'-TGTGGAATTCCTAGTCCAGAGTCTCC-3'), restricted with EcoRI and inserted into 

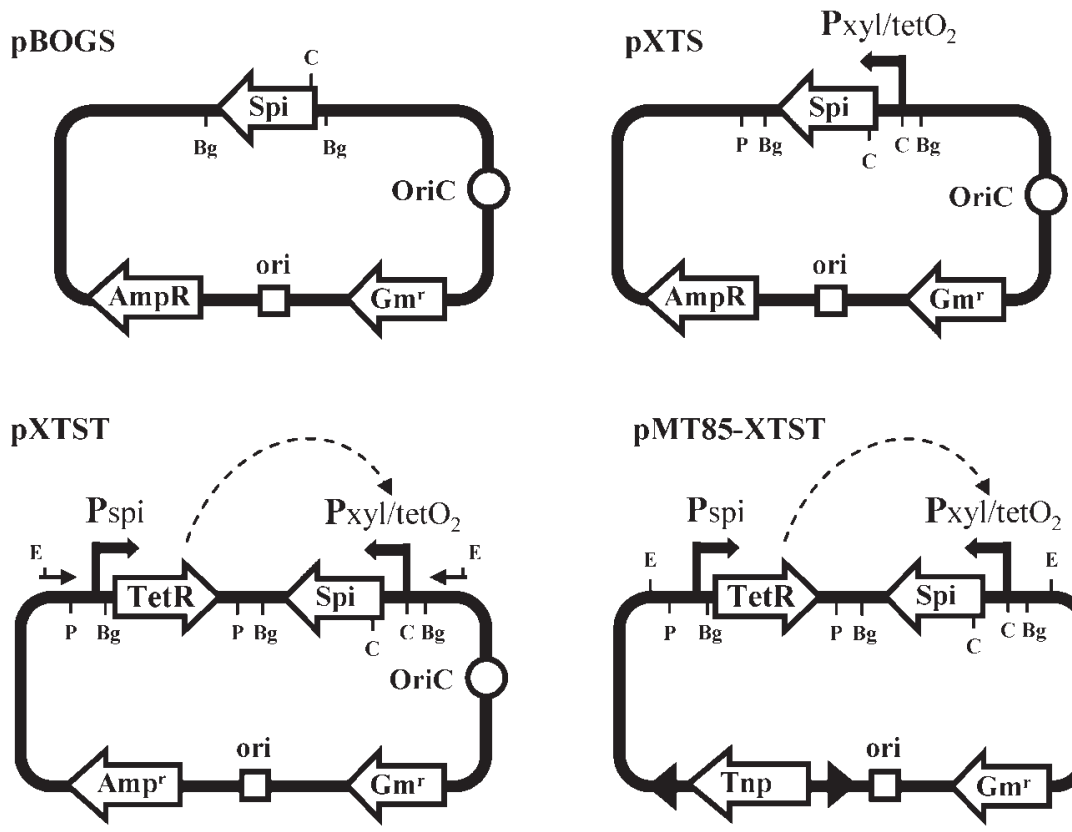

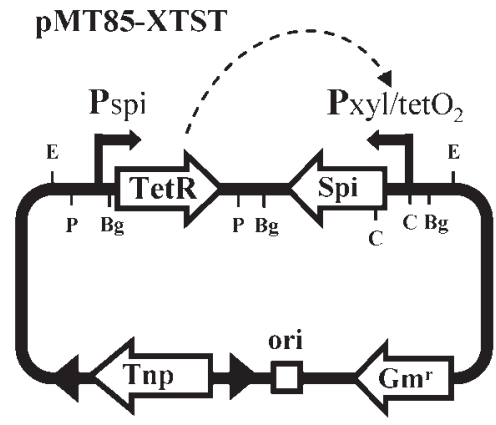

Fig. 1. Schematic representation of plasmids pBOGS, pXTS, pXTST and pMT85-XTST. OriC, S. citri chromosomal replication origin; ori, colE1 replication origin from $\mathrm{pBS}^{+} ; \mathrm{Amp}^{\mathrm{r}}$ and $\mathrm{Gm}^{r}$, genes conferring resistance to ampicillin and gentamicin, respectively. Tnp, transposase gene of Tn4001; TetR, tetracycline repressor gene from E. coli; Spi, S. citri spiralin gene devoid of its own promoter; Pxyl/ tetO $\mathrm{O}_{2}$, tetracycline-inducible promoter $x y / l$ tet $\mathrm{O}_{2}$ from $\mathrm{pWH105}$; Pspi, transcription promoter of the S. citri spiralin gene; $\mathrm{Bg}, \mathrm{Bg} / \mathrm{ll} ; \mathrm{C}$, Clal; E, EcoRl; P, Pstl. In pMT85-XTST, inverted repeat sequences of $\mathrm{Tn} 4001$ are indicated by black arrowheads in opposite orientation (note that the transposase gene is outside the transposed fragment). Primers XTST-EcoRI-F and XTST-EcoRI-R are indicated by thin horizontal arrows in PXTST.
EcoRI-linearized pMT85 (Zimmerman \& Herrmann, 2005) to yield pMT85-XTST (Fig. 1).

\begin{abstract}
Experimental transmission assay and artificial feeding of C. haematoceps. Experimental transmission of $S$. citri via injection into its leafhopper vector (C. haematoceps) and acquisition of spiroplasmas by feeding through a Parafilm membrane have been described previously (Foissac et al., 1996). Briefly, after a 10-14 day latent period on stock plants, the infected insects were caged on young periwinkle (Catharanthus roseus) plants (five insects per plant) for 2 weeks. Symptoms usually appeared within 2 weeks after insect removal. For tetracycline induction, symptomatic plants were watered with a $1 \mathrm{mg} \mathrm{ml}^{-1}$ tetracycline solution (or water for control plants) for 2-4 days before being tested for spiralin expression. For tetracycline induction in insects, the leafhoppers were injected with S. citri cultures and caged on healthy stock plants for 2 weeks to allow the spiroplasmas to multiply. The infected insects were then transferred to small cages (five insects per cage), in which a Parafilm membrane separated the insects from the artificial feeding solution (HS buffer) with no (control) or $25 \mu \mathrm{g}$ tetracycline $\mathrm{ml}^{-1}$. After a 3 day feeding period at $32{ }^{\circ} \mathrm{C}$, insects were removed from the cages and used for detection of spiralin by immunoblotting as described above. Determination of $S$. citri titres in plants and insects was carried out as described previously (Foissac et al., 1997).
\end{abstract}

\section{RESULTS AND DISCUSSION}

\section{Tetracycline-induced spiralin expression in S. citri GII3-9a3}

Spiralin is the major membrane protein of S. citri and can easily be detected when expressed in heterologous systems (Janis et al., 2005; Renaudin et al., 1995). Even though it has been thought to play a role in insect transmission (Killiny et al., 2005; Duret et al., 2003), this $26 \mathrm{kDa}$ lipoprotein is not essential for the spiroplasma to fulfil its infectious cycle (Duret et al., 2003). To construct the inducible spiralin gene expression system, we chose $\mathrm{P} x y \mathrm{l} /$ tet $\mathrm{O}_{2}$ (comprising a tandem tet $\mathrm{O}$ arrangement) as the tetracycline-inducible promoter because it was shown to be the most efficiently repressed by TetR and yet totally inducible by anhydrotetracycline in Bacillus subtilis (Kamionka et al., 2005). To assess whether the $x y l /$ tet $_{2}$ promoter was functional in S. citri, pXTS carrying the spiralin gene under the control of $\mathrm{Pxyl} /$ tet $_{2}$, was introduced into the spiralin-less mutant GII3-9a3 by transformation. As indicated by the immunoblots (Fig. 2a), spiralin expression was easily detected in GII3-9a3/ pXTS transformants (lane 3) but not in the control, nontransformed cells (lane 2). These results clearly indicated that the $x y l / t e t \mathrm{O}_{2}$ promoter did support transcription of

(a)
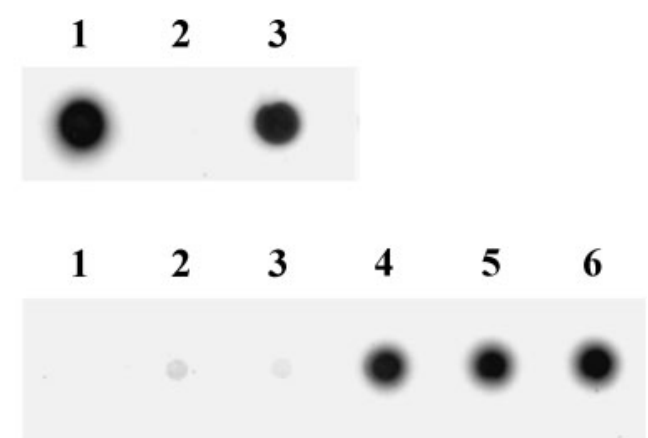

Fig. 2. Immunoblot detection of spiralin in whole-cell extracts from various $S$. citri strains. The blots were probed with rabbit antispiralin antibodies. (a) S. citri Gll3 wild-type (lane 1), spiralin-less mutant Gll3-9a3 (lane 2), GII3-9a3/pXTS (lane 3). (b) S. citri Gll39a3/pXTST uninduced (lane 1) or induced with 5, 10, 50, 100 and $1000 \mathrm{ng}$ tetracycline $\mathrm{ml}^{-1}$ (lanes 2-6, respectively). 
the spiralin gene in the spiroplasma cells. Nevertheless, the figure shows that the amount of spiralin produced in the $S$. citri transformants was significantly lower than that in the wild-type strain GII3 (lane 1). This suggests that, in contrast to the chromosomal spiralin gene promoter of $S$. citri GII3, the $x y l /$ tet $_{2}$ promoter of pXTS may not be recognized as a strong promoter by the $S$. citri RNA polymerase, albeit that the gene expression level may not be exclusively dependent on the promoter strength.

To evaluate the regulatory properties of the TetR repressor on the $x y l / t e t \mathrm{O}_{2}$ promoter in S. citri, the spiralin-less mutant GII3-9a3 was transformed by pXTST. In addition to the $x y l / t e t \mathrm{O}_{2}$ spiralin gene fragment, this plasmid contains the TetR repressor gene under the control of the constitutively active spiralin gene promoter (Fig. 1). This spiroplasmal promoter is known to support efficient transcription of cloned genes in S. citri as well as in animal mycoplasmas (Renaudin \& Lartigue, 2005; Janis et al., 2005). The gentamicin-resistant transformants were grown in the presence of various tetracycline concentrations and then the expression of spiralin was monitored by immunoblotting (Fig. 2b). The failure to detect spiralin in the absence of tetracycline (lane 1) clearly indicated that, in the absence of an activated transactivator, expression of spiralin from the $x y l / t e t \mathrm{O}_{2}$ promoter was tightly regulated by TetR. As expected, adding increasing concentrations of tetracycline resulted in induction of spiralin expression. Spiralin was detected at tetracycline concentrations ranging from 50 to $1000 \mathrm{ng} \mathrm{ml}^{-1}$ (lanes 4-6). Interestingly, the expression level of spiralin was quite similar to that of $S$. citri GII3-9a3 transformed by pXTS (Fig. 2a, lane 3), indicating that tetracycline concentrations as low as $50 \mathrm{ng}$ $\mathrm{ml}^{-1}$ (i.e. four times lower than the MIC for the wild-type strain GII3) were sufficient to completely eliminate TetR repressor control of $\mathrm{Pxyl} / \mathrm{tetO}_{2}$. Therefore it is expected that in S. citri, as in other organisms (Corrigan \& Foster, 2009), induction of gene expression by tetracycline does not necessarily require the use of a tetracycline-resistant strain such as GII3-9a3. The fact that the amount of spiralin produced in GII3-9a3/pXTST did not reach that produced in the wild-type strain GII3 certainly results from the lower strength of the $x y l / t e t O_{2}$ promoter as compared to that of the chromosome-encoded spiralin gene rather than from deficient tetracycline induction.

\section{Stable integration of pXTST into the S. citri GII3- 9a3 chromosome}

In S. citri, as in most Gram-positive bacteria, the oriC plasmids have a tendency to integrate into the host chromosome. During propagation of the spiroplasmal transformants, the oriC plasmids integrate through homologous recombination involving a single crossover at the oriC region. Once integrated, the plasmid sequences are stably maintained regardless of the presence or absence of selection pressure (Renaudin \& Lartigue, 2005). Because applying an antibiotic selection pressure in vivo in the spiroplasmal hosts (i.e. the leafhopper vector and the plant) would be technically difficult, we selected a pXTST transformant in which the plasmid had integrated into the chromosome and hence was expected to be stably maintained even in the absence of selection pressure. Individual transformants were grown in the presence of tetracycline and subcultured for five passages in the presence of gentamicin before subcloning by filtration $(0.22 \mu \mathrm{m})$ and plating onto solid medium with antibiotic. Plasmid integration into the host chromosome was checked by Southern blot hybridization of HincIIrestricted genomic DNAs from 10 individual colonies with the $\mathrm{Gm}^{\mathrm{r}}$ probe. In all 10 subclones tested, the $\mathrm{Gm}^{\mathrm{r}}$ probe did not reveal the $9.6 \mathrm{kbp}$ fragment corresponding to the linearized, free plasmid (Fig. 3, lanes 1 and 3). Instead, the detection of two fragments of 12 and $3.5 \mathrm{kbp}$ was consistent with the integration of pXTST by a single crossover recombination at the oriC region, as described in the case of oriC plasmid pBOT1 (Renaudin et al., 1995). To further confirm the stable maintenance of integrated pXTST, one such clone was subcultured for 10 additional passages in the absence of selection pressure and then plated with and without gentamicin. Similar c.f.u. counts were obtained in both conditions, indicating that pXTST was stably integrated into the chromosome and hence that this clone, named GII3-9a3/pXTST, could therefore be used for further in vivo experiments.

\section{Induction of spiralin expression in the S. citri leafhopper vector}

In S. citri-infected leafhoppers (C. haematoceps), the spiroplasmas are abundantly present in the haemolymph and in most of the insect organs. Therefore, induction of gene expression requires the inducer to cross the gut barrier to reach the spiroplasmas present in the haemocoel. To determine whether gene expression in S. citri could be

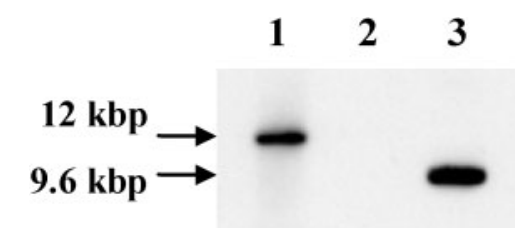

Fig. 3. Hybridization of Hincll-restricted DNA extracted from the Gll3-9a3/pXTST transformant (lane 1) as compared to $S$. citri GII3-9a3 (lane 2) and purified pXTST. The blot was hybidized with the $\mathrm{Gm}^{\mathrm{r}}$ probe. 
induced in vivo in the leafhopper vector, the insects were infected via injection of the $S$. citri transformant GII3-9a3/ pXTST as well as S. citri GII3 used as the control. After a 14 day latent period, the leafhoppers were fed through Parafilm membrane with sucrose solution without (control) or containing $25 \mu \mathrm{g}$ tetracycline $\mathrm{ml}^{-1}$. After feeding for $72 \mathrm{~h}$, spiralin production was detected by immunoblotting of leafhoppers extracts (Fig. 4a). Whereas extracts from insects fed without antibiotic yielded a very weak signal (lane 3) similar to that obtained with healthy insects (lane 2), a clear-cut spiralin signal was detected when the insects were fed with sucrose containing tetracycline (lane 4). In agreement with in vitro data, the level of spiralin expression from the $x y l / t e t \mathrm{O}_{2}$ promoter was lower than that in the wildtype strain GII3 (lane 1), where the spiralin gene is transcribed from its own promoter.

\section{Induction of spiralin expression in the S. citri host plant}

Several studies have reported on the bacteriostatic effect of tetracycline on mollicutes in infected plants, resulting in symptom remission (Singh et al., 2007; Wongkaew \& Fletcher, 2004). From these data, it was expected that tetracycline, when included in the watering solution, would reach the phloem sap in which the bacteria multiply, allowing induction of gene expression in planta. In the experiment of Fig. 4(b), periwinkle plants were experi-

(a)

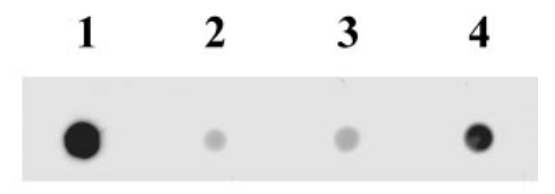

(b)



Fig. 4. (a) Expression of spiralin in leafhoppers infected with $S$. citri GII3-9a3/pXTST and fed with sucrose solution containing no (lane 3) or $25 \mu \mathrm{g}$ tetracycline $\mathrm{ml}^{-1}$ (lane 4). Extracts from healthy (lane 2) and S. citri Gll3-infected leafhoppers (lane 1) were used as negative and positive controls, respectively. Spiroplasma titres in the insects were: $9.2 \times 10^{5}, 2.3 \times 10^{5}$ and $2.3 \times 10^{5}$ c.f.u. per insect for S. citri Gll3, GII3-9a3/pXTST (uninduced) and GII39a3/pXTST (tetracycline induced), respectively. (b) In planta expression of spiralin by S. citri Gll3-9a3/pXTST. Extracts from Gll3-9a3/pXTST-infected periwinkle plants watered with water (lane 3) or with $1 \mathrm{mg}$ tetracycline $\mathrm{ml}^{-1}$ (lane 4) for $72 \mathrm{~h}$. Extracts from healthy periwinkle (lane 2) and from plants infected by S. citri Gll3 (lane 1) were used as positive and negative controls, respectively. The blots were probed with rabbit anti-spiralin polyclonal antibodies as the primary antibody. mentally infected by GII3-9a3 and GII3-9a3/pXTST through injection to the leafhopper vector. Four weeks after transmission, symptomatic plants were selected and watered with water alone (control) or with a $1 \mathrm{mg} \mathrm{ml}{ }^{-1}$ tetracycline solution for up to 4 days. Young symptomatic leaves were collected at various times and analysed by immunoblotting for spiralin expression. As indicated in Fig. 4(b), no spiralin was detected in the absence of tetracycline treatment. In contrast, spiralin expression was clearly detected at $72 \mathrm{~h}$ (lane 4), indicating that, at this stage, the tetracycline concentration in the phloem sap was high enough to induce expression of the TetR-regulated spiralin gene. No signal was detected at 24 and $48 \mathrm{~h}$ (data not shown).

\section{Induction of spiralin expression in M. agalactiae}

To determine whether the tetracycline-inducible, spiralin expression system could function in mollicutes other than S. citri, the tetR-P $x y l / t e t O_{2}$-spiralin cassette was introduced into the $M$. agalactiae chromosome. M. agalactiae type strain PG2 was transformed with the non-replicative plasmid pMT85-XTST, which carries the cassette and the gentamicin-resistance gene in between the inverted repeat sequences recognized by the encoded transposase (Fig. 1). Then, gentamicin-resistant transformants were selected and analysed for the presence of the transposed fragment by PCR (data not shown), prior to testing for spiralin expression. As shown in Fig. 5, no spiralin was detected in the absence of tetracycline (lane 1), indicating a tight control of $\mathrm{Pxyl} / \mathrm{tet}_{2}$ by TetR. This result proved the spiralin gene promoter to support efficient transcription of tet $R$ in $M$. agalactiae. It is consistent with previous data showing that the spiralin gene as well as the reporter gene lac $Z$ encoding $\beta$-galactosidase could be expressed in Mycoplasma capricolum from this spiroplasmal promoter (Janis et al., 2005). As shown in Fig. 5, induction of spiralin gene expression was achieved with tetracycline concentrations ranging from 50 to $250 \mathrm{ng} \mathrm{ml}^{-1}$ (lanes 2-4). In these experiments three distinct $M$. agalactiae transformants were examined. In all three, spiralin was equally expressed upon tetracycline induction and no spiralin was detected in the absence of induction (except for one transformant for which a hardly visible signal was detected on the blot). However, because of the low number of transformants

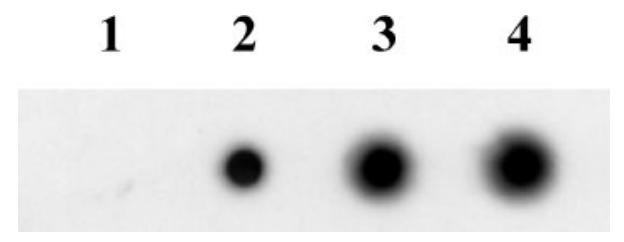

Fig. 5. Spiralin expression in $M$. agalactiae. Blots of whole-cell extracts from M. agalactiae PG2/pMT85-XTST uninduced (lane 1) or induced with 50, 100 and $250 \mathrm{ng}$ tetracycline $\mathrm{ml}^{-1}$ (lanes 2-4, respectively) were probed with rabbit anti-spiralin antibodies. 
examined, the occurrence in some cases of spiralin expression in the absence of tetracycline induction cannot be excluded.

\section{Conclusion}

In this study we have demonstrated that the tetracyclineinducible $x y l / t e t \mathrm{O}_{2}$ promoter, which was previously developed in the Gram-positive bacteria B. subtilis (Geissendörfer \& Hillen, 1990) and Staphylococcus aureus (Zhang et al., 2000), does function in the plant-pathogenic mollicute S. citri. Whereas in the absence of tetracycline, expression of spiralin was nearly undetectable, showing that the expression level of TetR from the spiralin gene promoter was high enough to tightly control the $x y l /$ tet $_{2}$ promoter, spiralin production was induced in a dosedependent manner in the presence of tetracycline. Besides in vitro studies, this inducible promoter system also proved to be functional in vivo, since spiralin gene induction was detected in spiroplasmas in the leafhopper vector as well as in the host plant. In previous studies, we have shown that the $S$. citri spiralin-less mutant GII3-9a3 is affected in its ability to cross the salivary gland barrier in the leafhopper vector. As a result, the mutant is transmitted at low efficiency as compared to the wild-type strain GII3 (Duret et al., 2003). Whether tetracycline-induced expression of spiralin did restore insect transmissibility of the GII3-9a3/ pXTST transformant has not been tested because we have shown previously that expression of spiralin in S. citri GII39a3 (even from its own promoter) did not fully restore the wild-type phenotype (unpublished data). Therefore, functional testing of tetracycline-inducible gene expression systems in S. citri would require the use of mutants with more clear-cut phenotypes.

Using the TetR-Pxyl/tet $\mathrm{O}_{2}$ system, tetracycline-induced expression of spiralin was also demonstrated in the ruminant pathogen $M$. agalactiae. In both organisms, expression of TetR resulted in a tight control of the $x y l /$ tet $\mathrm{O}_{2}$ promoter, and gene expression could be induced by subinhibitory concentrations of tetracycline. To our knowledge, this is the first description of an engineered, regulated gene expression system for use in the class Mollicutes.

S. citri, the aetiological agent of citrus stubborn disease (Saglio et al., 1973), and M. agalactiae, a small ruminant pathogen causing mastitis, arthritis and respiratory diseases (Bergonier et al., 1997), belong to two distinct phylogenetic groups. S. citri belongs to the Spiroplasma group, including the animal mycoplasmas of the M. mycoides cluster, whereas M. agalactiae fit in the Hominis group, which also includes important animal pathogens, such as Mycoplasma bovis (phylogenetically close to M. agalactiae) and Mycoplasma hyopneumoniae, as well as the human mycoplasma, Mycoplasma hominis (Maniloff, 2002). Therefore, the tetracycline-inducible gene expression system will certainly be relevant to other mollicutes, expanding the genetic toolbox for studying virulence and pathogenicity of these organisms. The possibility of replacing the native promoter of a target gene with a tightly regulated promoter whose activity can be controlled experimentally opens the way for the construction of conditional mutants of essential genes, which is crucial in the context of mollicutes, which are considered as 'minimal' organisms (Peterson \& Fraser, 2001).

\section{ACKNOWLEDGEMENTS}

We are grateful to Dr V. Coustou for the generous gift of pLew90. We thank M.-P. Dubrana for injecting spiroplasma cultures into leafhoppers. We also thank K. Guionneaud and D. Lacaze for growing plant and insects.

\section{REFERENCES}

André, A., Maccheroni, W., Doignon, F., Garnier, M. \& Renaudin, J. (2003). Glucose and trehalose PTS permeases of Spiroplasma citri probably share a single IIA domain, enabling the spiroplasma to adapt quickly to carbohydrate changes in its environment. Microbiology 149, 2687-2696.

André, A., Maucourt, M., Moing, A., Rolin, D. \& Renaudin, J. (2005). Sugar import and phytopathogenicity of Spiroplasma citri: glucose and fructose play distinct roles. Mol Plant Microbe Interact 18, 3342.

Bae, T. \& Schneewind, O. (2006). Allelic replacement in Staphylococcus aureus with inducible counter-selection. Plasmid 55, 58-63.

Bergonier, D., Berthelot, X. \& Poumarat, F. (1997). Contagious agalactia of small ruminants: current knowledge concerning epidemiology, diagnosis and control. Rev Sci Tech 16, 848-873.

Blokpoel, M. C., Murphy, H. N., O'Toole, R., Wiles, S., Runn, E. S., Stewart, G. R., Young, D. B. \& Robertson, B. D. (2005). Tetracyclineinducible gene regulation in mycobacteria. Nucleic Acids Res 33, e22.

Breton, M., Duret, S., Arricau-Bouvery, N., Béven, L. \& Renaudin, J. (2008). Characterizing the replication and stability regions of Spiroplasma citri plasmids identifies a novel replication protein and expands the genetic toolbox for plant-pathogenic spiroplasmas. Microbiology 154, 3232-3244.

Carroll, P., Brown, A. C., Hartridge, A. R. \& Parish, T. (2007). Expression of Mycobacterium tuberculosis Rv1991c using an arabinose-inducible promoter demonstrates its role as a toxin. FEMS Microbiol Lett 274, 73-82.

Chopra-Dewasthaly, R., Marenda, M., Rosengarten, R. A., Jechlinger, W. \& Citti, C. (2005a). Construction of the first shuttle vectors for gene cloning and homologous recombination in Mycoplasma agalactiae. FEMS Microbiol Lett 253, 89-94.

Chopra-Dewasthaly, R., Zimmermann, M., Rosengarten, R. \& Citti, C. (2005b). First steps towards the genetic manipulation of Mycoplasma agalactiae and Mycoplasma bovis using the transposon Tn4001mod. Int J Med Microbiol 294, 447-453.

Cordova, C. M., Lartigue, C., Sirand-Pugnet, P., Renaudin, J., Cunha, R. A. \& Blanchard, A. (2002). Identification of the origin of replication of the Mycoplasma pulmonis chromosome and its use in oriC replicative plasmids. J Bacteriol 184, 5426-5435.

Corrigan, R. M. \& Foster, T. J. (2009). An improved tetracyclineinducible expression vector for Staphylococcus aureus. Plasmid 61, 126-129. 
Corrigan, R. M., Rigby, D., Handley, P. \& Foster, T. J. (2007). The role of Staphylococcus aureus surface protein SasG in adherence and biofilm formation. Microbiology 153, 2435-2446.

Duret, S., Danet, J. L., Garnier, M. \& Renaudin, J. (1999). Gene disruption through homologous recombination in Spiroplasma citri: an scm1-disrupted motility mutant is pathogenic. J Bacteriol 181, 7449-7456.

Duret, S., Berho, N., Danet, J. L., Garnier, M. \& Renaudin, J. (2003). Spiralin is not essential for helicity, motility, or pathogenicity but is required for efficient transmission of Spiroplasma citri by its leafhopper vector Circulifer haematoceps. Appl Environ Microbiol 69, $6225-6234$

Duret, S., André, A. \& Renaudin, J. (2005). Specific gene targeting in Spiroplasma citri: improved vectors and production of unmarked mutations using site-specific recombination. Microbiology 151, 2793 2803.

Foissac, X., Danet, J. L., Saillard, C., Whitcomb, R. F. \& Bové, J. M. (1996). Experimental infections of plant by spiroplasmas. In Molecular and Diagnostic Procedures in Mycoplasmology, vol. 2, pp. 385-389. Edited by S. Razin \& J. G. Tully. New York: Academic Press.

Foissac, X., Danet, J. L., Saillard, C., Gaurivaud, P., Laigret, F., Pare, C. \& Bové, J. M. (1997). Mutagenesis by insertion of Tn 4001 into the genome of Spiroplasma citri: characterization of mutants affected in plant pathogenicity and transmission to the plant by the leafhopper vector Circulifer haematoceps. Mol Plant Microbe Interact 10, 454-461.

Gaurivaud, P., Danet, J. L., Laigret, F., Garnier, M. \& Bové, J. M. (2000). Fructose utilization and phytopathogenicity of Spiroplasma citri. Mol Plant Microbe Interact 13, 1145-1155.

Gaurivaud, P., Laigret, F., Garnier, M. \& Bové, J. M. (2001). Characterization of FruR as a putative activator of the fructose operon of Spiroplasma citri. FEMS Microbiol Lett 198, 73-78.

Geissendörfer, M. \& Hillen, W. (1990). Regulated expression of heterologous genes in Bacillus subtilis using the Tn10 encoded tet regulatory elements. Appl Microbiol Biotechnol 33, 657-663.

Halbedel, S., Eilers, H., Jonas, B., Busse, J., Hecker, M., Engelmann, S. \& Stulke, J. (2007). Transcription in Mycoplasma pneumoniae: analysis of the promoters of the ackA and ldh genes. J Mol Biol 371, 596-607.

Jacob, C., Nouzieres, F., Duret, S., Bové, J. M. \& Renaudin, J. (1997). Isolation, characterization, and complementation of a motility mutant of Spiroplasma citri. J Bacteriol 179, 4802-4810.

Janis, C., Lartigue, C., Frey, J., Wroblewski, H., Thiaucourt, F., Blanchard, A. \& Sirand-Pugnet, P. (2005). Versatile use of oriC plasmids for functional genomics of Mycoplasma capricolum subsp. capricolum. Appl Environ Microbiol 71, 2888-2893.

Janis, C., Bischof, D., Gourgues, G., Frey, J., Blanchard, A. \& SirandPugnet, P. (2008). Unmarked insertional mutagenesis in the bovine pathogen Mycoplasma mycoides subsp. mycoides SC: characterization of a lppQ mutant. Microbiology 154, 2427-2436.

Kamionka, A., Bertram, R. \& Hillen, W. (2005). Tetracyclinedependent conditional gene knockout in Bacillus subtilis. Appl Environ Microbiol 71, 728-733.

Killiny, N., Castroviejo, M. \& Saillard, C. (2005). Spiroplasma citri spiralin acts in vitro as a lectin binding to glycoproteins from its insect vector Circulifer haematoceps. Phytopathology 95, 541-548.

Killiny, N., Batailler, B., Foissac, X. \& Saillard, C. (2006). Identification of a Spiroplasma citri hydrophilic protein associated with insect transmissibility. Microbiology 152, 1221-1230.

Lartigue, C., Duret, S., Garnier, M. \& Renaudin, J. (2002). New plasmid vectors for specific gene targeting in Spiroplasma citri. Plasmid 48, 149-159.
Lartigue, C., Blanchard, A., Renaudin, J., Thiaucourt, F. \& SirandPugnet, P. (2003). Host specificity of mollicutes oriC plasmids: functional analysis of replication origin. Nucleic Acids Res 31, 66106618.

Lee, S. W., Browning, G. F. \& Markham, P. F. (2008). Development of a replicable oriC plasmid for Mycoplasma gallisepticum and Mycoplasma imitans, and gene disruption through homologous recombination in M. gallisepticum. Microbiology 154, 2571-2580.

Maniloff, J. (2002). Phylogeny and evolution. In Molecular Biology and Pathogenicity of Mycoplasmas, pp. 31-43. Edited by S. Razin \& R. Herrmann. New York: Kluwer Academic/Plenum.

Musatovova, O., Dhandayuthapani, S. \& Baseman, J. B. (2006). Transcriptional heat shock response in the smallest known selfreplicating cell, Mycoplasma genitalium. J Bacteriol 188, 2845-2855.

Peterson, S. N. \& Fraser, C. M. (2001). The complexity of simplicity. Genome Biol 2, COMMENT2002.

Renaudin, J. (2002). Extrachromosomal elements and gene transfer. In Molecular and Pathogenicity of Mycoplasmas, pp. 347-370. Edited by S. Razin \& R. Herrmann. New York: Kluwer Academic/Plenum.

Renaudin, J. \& Lartigue, C. (2005). oriC plasmids as gene vectors for mollicutes. In Mycoplasmas: Pathogenesis, Molecular Biology, and Emerging Strategies for Control, pp. 3-30. Edited by A. Blanchard \& G. Browning. Norwich, UK: Horizon Scientific Press.

Renaudin, J., Marais, A., Verdin, E., Duret, S., Foissac, X., Laigret, F. \& Bové, J. M. (1995). Integrative and free Spiroplasma citri oriC plasmids: expression of the Spiroplasma phoeniceum spiralin in Spiroplasma citri. J Bacteriol 177, 2870-2877.

Rouch, D. A., Byrne, M. E., Kong, Y. C. \& Skurray, R. A. (1987). The aacA-aphD gentamicin and kanamycin resistance determinant of Tn4001 from Staphylococcus aureus: expression and nucleotide sequence analysis. J Gen Microbiol 133, 3039-3052.

Saglio, P., Lhospital, M., Laflèche, D., Dupont, G., Bové, J. M., Tully, J. G. \& Freundt, E. A. (1973). Spiroplasma citri gen. and sp. nov.: a mycoplasma-like organism associated with stubborn disease of citrus. Int J Syst Bacteriol 23, 191-204.

Singh, S. K., Aminuddin, S. K., Srivastava, P., Singh, B. R. \& Khan, J. A. (2007). Production of phytoplasma-free plants from yellow leaf diseased Catharanthus roseus (L.) G. Don. J Plant Dis Prot 114, 2-5.

Sirand-Pugnet, P., Lartigue, C., Marenda, M., Jacob, D., Barré, A., Barbe, V., Schenowitz, C., Mangenot, S., Couloux, A. \& other authors (2007). Being pathogenic, plastic, and sexual while living with a nearly minimal bacterial geome. PLoS Genet 3, e75.

Stamburski, C., Renaudin, J. \& Bové, J. M. (1991). First step toward a virus-derived vector for gene cloning and expression in spiroplasmas, organisms which read UGA as a tryptophan codon - synthesis of chloramphenicol acetyltransferase in Spiroplasma citri. J Bacteriol 173, 2225-2230.

Vignault, J. C., Bové, J. M., Saillard, C., Vogel, R., Faro, A., Venegas, L., Stemmer, W., Aoki, S., McCoy, R. E. \& other authors (1980). Mise en culture de spiroplasmes à partir de matériel végétal et d'insectes provenant de pays circum méditerranéens et du Proche Orient. $C R$ Acad Sci Paris 290, 775-780.

Weiner, J., III, Zimmerman, C. U., Gohlmann, H. W. \& Herrmann, R. (2003). Transcription profiles of the bacterium Mycoplasma pneumoniae grown at different temperatures. Nucleic Acids Res 31, 63066320.

Weisburg, W. G., Tully, J. G., Rose, D. L., Petzel, J. P., Oyaizu, H., Yang, D., Mandelco, L., Sechrest, J., Lawrence, T. G. \& other authors (1989). A phylogenetic analysis of the mycoplasmas: basis for their classification. J Bacteriol 171, 6455-6467. 
Whitcomb, R. F. (1983). Culture media for spiroplasma. In Methods in Mycoplasmology, vol. I, pp. 147-158. Edited by S. Razin \& J. G. Tully. New York: Academic Press.

Wongkaew, P. \& Fletcher, J. (2004). Sugar cane white leaf phytoplasma in tissue culture: long-term maintenance, transmission, and oxytetracycline remission. Plant Cell Rep 23, 426-434.

Zhang, L., Fan, F., Palmer, L. M., Lonetto, M. A., Petit, C., Voelker, L. L., St John, A., Bankosky, B., Rosenberg, M. \& other authors (2000).
Regulated gene expression in Staphylococcus aureus for identifying conditional lethal phenotypes and antibiotic mode of action. Gene 255, 297-305.

Zimmerman, C. U. \& Herrmann, R. (2005). Synthesis of a small, cysteine-rich, 29 amino acids long peptide in Mycoplasma pneumoniae. FEMS Microbiol Lett 253, 315-321.

Edited by: C. A. Boucher 